\title{
Efficiency and Response to Nitrogen Use in Maize Genotypes for Silage Production in Tropical Climate
}

\author{
Weder Ferreira dos Santos ${ }^{1}$, Osvaldo José Ferreira Junior ${ }^{2}$, \\ Lucas Carneiro Maciel ${ }^{3^{*}}$, Joênes Mucci Peluzio ${ }^{2}$, Flávio Sérgio Afférri ${ }^{4}$, \\ Layanni Ferreira Sodré ${ }^{3}$, Lucas Alves de Faria ${ }^{2}$, Lucas Sodré Vieira ${ }^{3}$, \\ Adriano Silveira Barbosa ${ }^{2}$ and Rafael Marcelino da Silva ${ }^{3}$
}

${ }^{1}$ Department of Bioprocess Engineering and Biotechnology, Federal University of Tocantins, Gurupi, Tocantins, Brazil.

${ }^{2}$ Department of Plant Production, Federal University of Tocantins, Gurupi, Tocantins, Brazil. ${ }^{3}$ Department of Agronomy, Federal University of Tocantins, Gurupi, Tocantins, Brazil. ${ }^{4}$ Center for Natural Sciences, Federal University of São Carlos, Buri, São Paulo, Brazil.

Authors' contributions

This work was carried out in collaboration among all authors. Authors WFS, OJFJ, LCM and JMP designed the study and performed the analysis. Authors FSA, LFS, LAF and LSV managed the study and helped in the interpretation of the results. Authors ASB and RMS managed the literature searches. All authors read and approved the final manuscript.

Article Information

DOI: $10.9734 / A R R B / 2020 / v 35 i 930281$ Editor(s):

(1) Tunira Bhadauria, Kanpur University, India. Reviewers:

(1) Gean Charles Monteiro, Sao Paulo State University, Brazil. (2) Roxana Horoias, Probstdorfer Saatzucht Romania SRL, Romania. Complete Peer review History: http://www.sdiarticle4.com/review-history/60524

Original Research Article

Received 19 June 2020

Accepted 24 August 2020

Published 16 September 2020

\section{ABSTRACT}

Aims: This study aimed to select efficient and responsive maize genotypes to the use of nitrogen for silage.

Study Design: The experimental design was randomized blocks in a $2 \times 11$ factorial scheme, the first factor being two nitrogen levels: $165 \mathrm{~kg} \mathrm{ha}^{-1}$ of $\mathrm{N}$ and $15 \mathrm{~kg} \mathrm{ha}^{-1}$ of $\mathrm{N}$, and second factor eleven maize genotypes: BRS 3046, M 274, AG 8088PRO2, ANHEMBI, PR 27D28, AG 1051, P33-16, P33-11, P29-M12, P36-19, and P40-8.

Place and Duration of Study: The experiment was carried out in the 2017/18 harvest at Sítio Vitória (8॰18'32" S, 50³6'58" W), located in the municipality of Santa Maria das Barreiras, southern region of Pará state, Brazil. 
Methodology: Sowing fertilization was performed in the furrow with $300 \mathrm{~kg} \mathrm{ha}^{-1}$ of NPK 5-25-15. Topdressing nitrogen fertilization was performed only at high $\mathrm{N}$, having as source urea $(45 \% \mathrm{~N})$ at a dose of $150 \mathrm{~kg} \mathrm{ha}^{-1}$ of $\mathrm{N}$. Parceled in stages $\mathrm{V} 4$ and $\mathrm{V} 8$. The shoot fresh mass was evaluated at stages R4 and R5, with the cut performed $20 \mathrm{~cm}$ from the soil.

Results: The highest shoots fresh masses were obtained in treatments with high use of $\mathrm{N}$, with a general mean of $628 \mathrm{~g} \mathrm{plant}^{-1}$. The mean response of $1.87 \mathrm{~g}$ of plants per kg of $\mathrm{N}$ applied. Genotypes M 274, AG 8088PRO2, PR 27D28, AG 1051 and $P$ 36-19 were efficient to use N. Genotypes AG 8088PRO2, PR 27D28, P29-M12, and P 36-19 were classified as responsive to N application.

Conclusion: Genotypes AG 8088PRO2, PR 27D28 and P36-19 were efficient in use and responsive to nitrogen application. And they are recommended for cultivation with low and high technological level.

Keywords: Abiotic stress; forage; nitrogen fertilization; Zea mays $L$.

\section{INTRODUCTION}

To supply the nutrition of animals by protein (cattle, pigs and poultry), several forages have been studied. Among the forages for silage confection, maize is considered the standard crop. Because it presents favorable characteristics, such as high dry matter production per hectare, flexibility at the sowing time, good fermentation patterns, high nutritional value, excellent energy concentration, low fiber content and among others [1].

To increase maize yield and consequently obtain good silage, care is required with all stages of production, from planting to harvesting. The management of nitrogen fertilization is one of the cares that requires greater attention because it is directly related to high crop yields, especially for grasses [2].

The response of maize to nitrogen fertilization occurs because nitrogen $(\mathrm{N})$ participates in important plant metabolisms being a constituent of nucleic acids, proteins, enzymes, coenzymes, phytochrome and chlorophyll [3], this nutrient should be used in adequate quantities and times for better productive performance of the crop [4]. Also, $\mathrm{N}$ is responsible for vegetative growth, directly influencing grain yield [5]. According to Bender et al. [6], $\mathrm{N}$ is the most exported element in maize, and about $64 \%$ of it is translocated from soil to grains.

Every year, large amounts of maize genotypes are commercialized, and these have variability in productivity, among other production characteristics. This variability is due to the interaction between genotype and environment, and evaluation is necessary through experimentation to establish the potentialities and weaknesses of these genotypes in different regions, that is, in different climatic conditions [7].

Maize production is influenced by several factors, such as soil correction and soil fertilization. But one of the main factors is genetics. That's why. the identification of more efficient and/or nitrogen-responsive genotypes will contribute to higher crop yields in different circumstances [8].

Considering these points, the present study aims to evaluate and select maize genotypes that are efficient and responsive to the use of $\mathrm{N}$ for silage production in tropical climate of the southern region of the State of Pará, Brazil.

\section{MATERIALS AND METHODS}

The experiment was carried out in the 2017/18 harvest at Sítio Vitória $\left(8^{\circ} 18^{\prime} 32^{\prime \prime} \mathrm{S}, 50^{\circ} 36^{\prime} 58^{\prime \prime} \mathrm{W}\right.$, 278 meters altitude), located in the municipality of Santa Maria das Barreiras, southern region of Pará state, Brazil. The climate of the region (Fig. 1) was classified as Aw [9].

Sowing was carried out on November 14, 2017. The final density obtained was 55,555 plants ha1 . The soil of the experimental area, in the layer of $0-20 \mathrm{~cm}$, presented $150 \mathrm{~g} \mathrm{~kg}^{-1}$ of clay, and the following chemical characteristics: $4.8 \mathrm{pH} \mathrm{CaCl}$, $17 \mathrm{~g} \mathrm{~kg}^{-1}$ organic matter, $0.2 \mathrm{cmol}_{\mathrm{c}} \mathrm{dm}^{-3}$ aluminum, $1.7 \mathrm{cmol}_{\mathrm{c}} \mathrm{dm}^{-3}$ calcium, $0.3 \mathrm{cmol}_{\mathrm{c}} \mathrm{dm}^{-3}$ magnesium, $4.9 \mathrm{mg} \mathrm{dm}^{-3}$ phosphorus (Mehlich1), $43 \mathrm{mg} \mathrm{dm}^{-3}$ potassium, and $5.21 \mathrm{cmol}_{\mathrm{c}} \mathrm{dm}^{-3}$ cation exchange capacity. Sowing fertilization was performed in the furrow with $300 \mathrm{~kg} \mathrm{ha}^{-1}$ of NPK 5-25-15 [11]. 


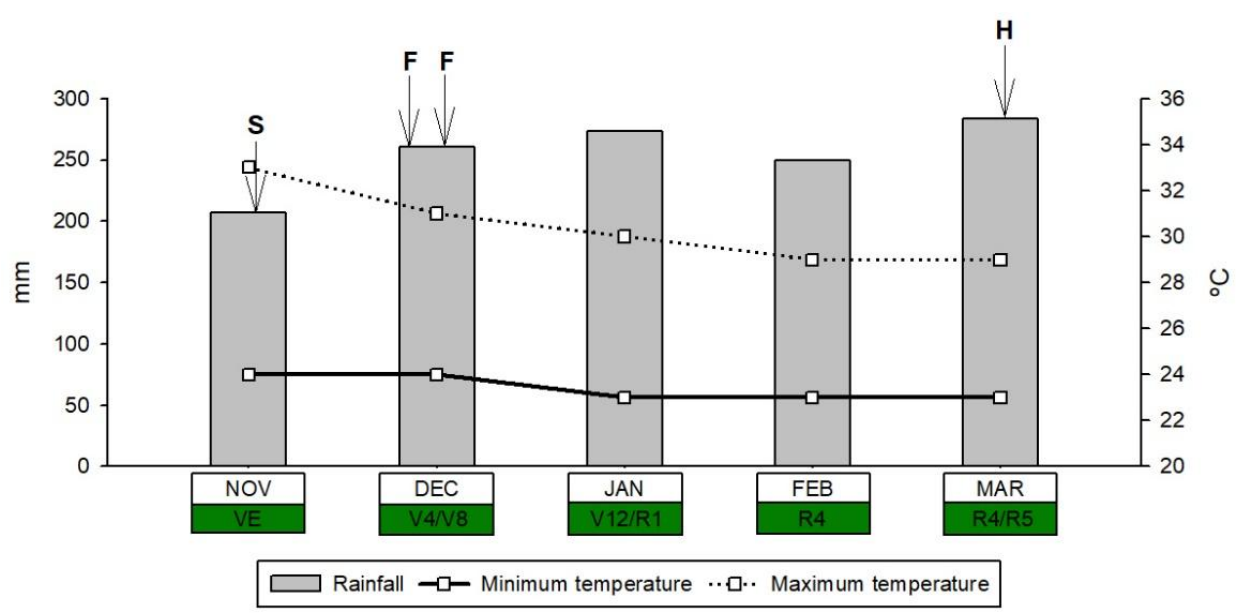

Fig. 1. Mean temperature $\left({ }^{\circ} \mathrm{C}\right)$ and rainfall $(\mathrm{mm})$ in the municipality of Santa Maria das Barreiras, Pará State, Brazil

S: sowing, F: topdressing $N$ fertilization, $H$ : harvest. Adapted from Climatempo [10]

A randomized block design with three replications was used. The treatments were arranged in the factorial scheme $2 \times 11$. The first factor consisted of contrasting nitrogen levels: high $\mathrm{N}\left(165 \mathrm{~kg} \mathrm{ha}^{-1}\right)$ and low $\mathrm{N}\left(15 \mathrm{~kg} \mathrm{ha}^{-1}\right)$. The second factor consisted of eleven maize genotypes (Table 1). The experimental plot consisted of four rows of 5.0 meters. All maize genotypes have a good adaptation in tropical climate.

Topdressing nitrogen fertilization was performed only at high $\mathrm{N}$, having as source urea $(45 \% \mathrm{~N})$ at a dose of $150 \mathrm{~kg} \mathrm{ha}{ }^{-1}$ of $\mathrm{N}$. Half was applied in stage V4 and the other half in stage V8. Low and high contents of $\mathrm{N}$ were considered for lower and increase expected forage yield [11].

Weed control was performed at stage V4 using Atrazine $\left(2.000 \mathrm{~kg}\right.$ i.a. ha $\left.{ }^{-1}\right)$. Three applications of Permethrin $\left(0.025 \mathrm{~kg}\right.$ i.a. $\left.\mathrm{ha}^{-1}\right)$ were performed to control Spodoptera frugiperda in stages V4, $\mathrm{V} 8$ and $\mathrm{V} 12$.

The shoot fresh mass (SFM) was evaluated in ten plants of the two central rows discarding 0.5 meters from the extremities. The plants were harvested at stages R4 and R5, with the cut performed $20 \mathrm{~cm}$ from the soil.

To identify efficient genotypes regarding the use of $\mathrm{N}$ and responsive to its application, the methodology proposed by Fageria \& Kluthcouski [13] was used. By this methodology, the efficiency corresponding to the mean SFM below $\mathrm{N}$. And the answer was given by the equation:

$$
\text { Response }=\frac{\text { SFM }(\text { High } \mathrm{N})-\mathrm{SFM}(\text { Low } \mathrm{N})}{\mathrm{N} \text { in high }-\mathrm{N} \text { in low }}
$$

Table 1. Description of eleven maize genotypes used in the experiment

\begin{tabular}{lll}
\hline Genotype & Genetic base & Company \\
\hline BRS 3046 & Triple hybrid & EMBRAPA \\
M 274 & Open-pollinated population & Priorizi Seeds \\
AG 8088PRO2 & Simple hybrid & Agroceres Seeds \\
ANHEMBI & Open-pollinated population & Priorizi Seeds \\
PR 27D28 & Simple hybrid & Priorizi Seeds= \\
AG 1051 & Double hybrid & Agroceres Seeds \\
P33-16 & Inbred lines & Federal University of Tocantins \\
P33-11 & Inbred lines & Federal University of Tocantins \\
P29-M12 & Inbred lines & Federal University of Tocantins \\
P36-19 & Inbred lines & Federal University of Tocantins \\
P40-8 & Inbred lines & Federal University of Tocantins \\
\hline
\end{tabular}


The data were submitted to the normality test. Then, variance analysis was performed. The means of genotypes were compared with the Scott and Knott test [14], at 5\% significance. Statistical analyses were performed in the SISVAR program, version 5.5 [15]. The efficiency and response data were presented in a graph, using SigmaPlot software.

\section{RESULTS AND DISCUSSION}

The analysis of variance showed a significant effect for $\mathrm{N}$ levels, genotype, and interaction (Table 2). The latter indicates $(N \times G)$ the existence of differential behavior of genotypes according to $N$ levels $[16,17]$. The coefficient of variation was classified as low and indicated good experimental accuracy [18].

In high $\mathrm{N}$ (Table 3 ) there was a higher overall mean of SFM (628 $\mathrm{g} \mathrm{plant}^{-1}$ ) when compared to the low $\mathrm{N}$ assay, with $348 \mathrm{~g} \mathrm{plant}^{-1}$. For all genotypes, there was a significant increase of SFM from low $\mathrm{N}$ to high $\mathrm{N}$, indicating the need to use a higher level of $\mathrm{N}$ so that a higher production of fresh matter can be obtained.

The highest SFM in high $\mathrm{N}$ treatments to low $\mathrm{N}$ occurred probably due to a greater contribution of the ear mass. According to Neumann et al. [19], the highest percentage contribution in the ensiled material comes from the mass of the ear $(40.48 \%)$, followed by the stem $(25.68 \%)$, the leaves (19.38\%) and bracts (14.45\%).

In plants with a high dose of $\mathrm{N}$, there is a higher translocation of carbohydrates to the roots, resulting in root system development and more efficient use of nitrogen, present or added to the soil through the use of fertilizers [20], reflecting an increase in silage production [21].

$\mathrm{N}$ is the nutrient required in greater quantity by the crop, and may limit the SFM of genotypes. Santos et al. [16], and Silva et al. [17] also found significant differences in several characteristics when maize genotypes were grown under high $\mathrm{N}$ and low $\mathrm{N}$.

Table 2. Analysis of variance of shoot fresh mass $\left(\mathrm{g} \mathrm{plant}^{-1}\right)$ of eleven maize genotypes as a function of nitrogen use in tropical climate

\begin{tabular}{lll}
\hline Source of variation & Degree of freedom & Mean square \\
\cline { 3 - 3 } & & Shoot fresh mass \\
\hline Nitrogen $(\mathrm{N})$ & 1 & $1305322.03^{*}$ \\
Genotype $(\mathrm{G})$ & 10 & $70835.21^{*}$ \\
Interaction $(\mathrm{N} \times \mathrm{G})$ & 10 & $15663.13^{*}$ \\
Block & 2 & 63.8 \\
Error & 42 & 553.66 \\
\hline Mean & 195 \\
Coefficients of variation (\%) & *: significant by the $F$ test at $5 \%$ significance
\end{tabular}

Table 3. Shoot fresh mass and response to nitrogen use of eleven maize genotypes in tropical climate

\begin{tabular}{llcl}
\hline Genotype & \multicolumn{2}{c}{ Shoot fresh mass (g plant $^{-1}$ ) } & Response \\
\cline { 2 - 3 } & High N & Low N & 1,44 \\
\hline BRS 3046 & $539 \mathrm{Af}$ & $323 \mathrm{Bc}$ & 0.67 \\
M 274 & $518 \mathrm{Af}$ & $418 \mathrm{Bb}$ & 2.79 \\
AG 8088PRO2 & $904 \mathrm{Aa}$ & $486 \mathrm{Ba}$ & 1.86 \\
ANHEMBI & $568 \mathrm{Af}$ & $288 \mathrm{Bc}$ & 2.61 \\
PR 27D28 & $840 \mathrm{Ab}$ & $449 \mathrm{Ba}$ & 1.23 \\
AG 1051 & $595 \mathrm{Ae}$ & $410 \mathrm{Bb}$ & 1.28 \\
P33-16 & $464 \mathrm{Ag}$ & $272 \mathrm{Bd}$ & 1.83 \\
P33-11 & $522 \mathrm{Af}$ & $248 \mathrm{Bd}$ & 2.66 \\
P29-M12 & $661 \mathrm{Ad}$ & $263 \mathrm{Bd}$ & 2.30 \\
P36-19 & $759 \mathrm{Ac}$ & $414 \mathrm{Bb}$ & 1.85 \\
P40-8 & $535 \mathrm{Af}$ & $257 \mathrm{Bd}$ & 1.87 \\
Mean & 628 & 348 & \\
Means followed by the same lowercase letter in the column and uppercase in the row, belong to the same group, &
\end{tabular}


In high $\mathrm{N}$, seven groups of means were formed in high $\mathrm{N}$, where genotype AG 8088PRO2 (904 g plant $^{-1}$ ) and genotype P33-16 (464 g plant ${ }^{-1}$ ) obtained the highest and lowest mean, respectively, when compared with the other genotypes.

For the low $\mathrm{N}$ environment, genotypes $\mathrm{AG}$ 8088PRO2 (487 g plant $^{-1}$ ) and PR 27D28 (449 g plant $^{-1}$ ) belong to the group with the highest mean. Genotypes P33-16 (272 $\mathrm{g} \mathrm{plant}^{-1}$ ), P29M12 (248 g plant $^{-1}$ ), P36-19 (263 g plant $^{-1}$ ) and P40-8 (257 g plant $^{-1}$ ) obtained the lowest SFM values.

The response to $\mathrm{N}$ use ranged from 0.67 to 2.79 $\mathrm{g}$ of plant per $\mathrm{kg}$ of $\mathrm{N}$ applied, achieved by genotypes M 274 and AG 8088PRO2, respectively. Cancellier et al. [22] in the study with twenty-five genotypes obtained a mean of 1.52 , lower than the mean of this study.

On the other hand, Fernandes et al. [23], in a study involving five doses of $\mathrm{N}$, and Rodrigues et al. [24], in a study with four nitrogen sources, obtained mean responses of 2.70 and 2.91, respectively, which were higher than the means of this study.

Using the methodology of Fageria and Kluthcouski [13], the genotypes were classified according to the response efficiency in the use of $\mathrm{N}$ (Fig. 2). For this classification, the media of the genotypes were compared with the general mean.

By this methodology, the efficiency corresponding to the mean SFM of each genotype in low $\mathrm{N}$. On the other hand, the response to the application of $\mathrm{N}$, for each genotype, resulted from the difference of SFM obtained in high $\mathrm{N}$ and low $\mathrm{N}$ divided by the difference between the $\mathrm{N}$ levels used in high $\mathrm{N}$ and low $\mathrm{N}$.

The genotypes classified as efficient to use $\mathrm{N}$ (Quadrant I and IV) were: M 274, AG 8088PRO2, $P R$ 27D28, AG 1051 and P36-19. These are indicated for production with a low technological level, as they produce well under conditions of low use of N. Of these, genotypes M 274 and AG 1051 were classified as non-responsive, i.e., despite producing well under conditions of low $\mathrm{N}$ utilization, they do not respond well to increasing levels of $\mathrm{N}$ [17].

Genotypes AG 8088PRO2, PR 27D28 and P3619 were also classified as responsive (Quadrant I and II), together with P29-M12. These genotypes are recommended for production at a high technological level, as they can respond well to increasing levels of the nutrient. On the other hand, genotype P29-M12 classified as inefficient, that is, as much as it can respond well to increasing levels of $\mathrm{N}$, it does not produce well under low use of $\mathrm{N}$ [17].

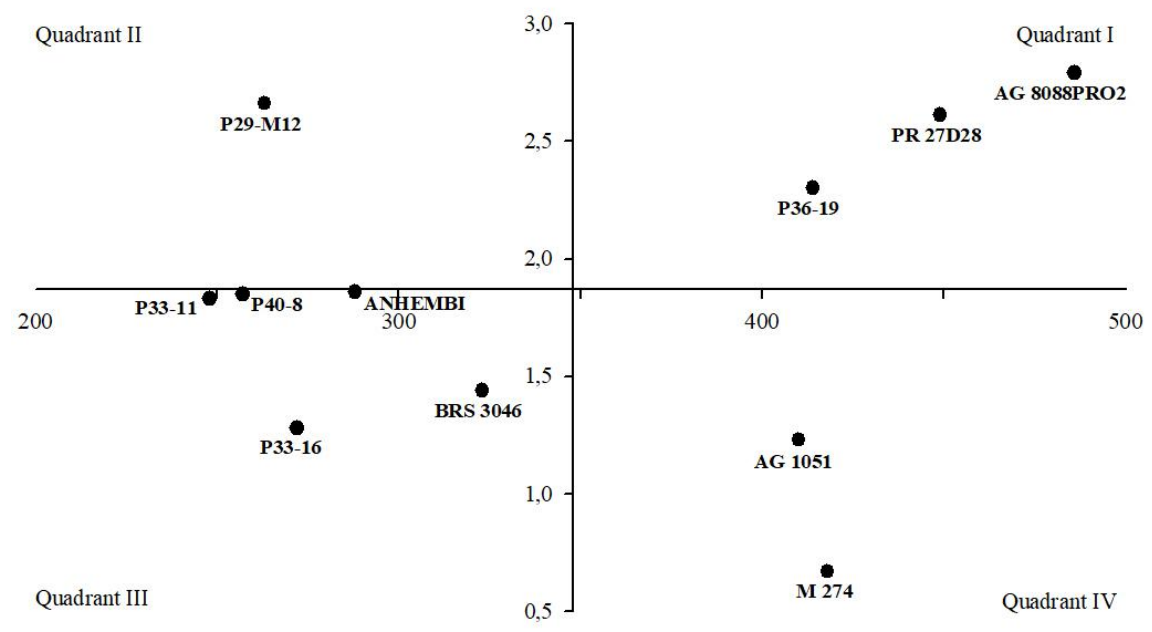

Fig. 2. Efficiency in the use and response to nitrogen application of eleven maize genotypes in tropical climate 
Still following the methodology, it was also possible to distinguish the genotypes that are non-efficient and non-responsive to the use of $\mathrm{N}$ : BRS 3046, ANHEMBI, P33-16, P33-11 and P408 , which are not indicated for any technological level or cultivation, because they produce poorly with low or high use of $\mathrm{N}$ [17].

This study allowed the classification of genotypes for efficiency and response to nitrogen use. This result helps the choice of genotypes according to the production environment. Contributing to increased yield and elevation of nitrogen efficient use.

\section{CONCLUSION}

The genotypes show different responses to nitrogen application in tropical climate. Genotypes AG 8088PRO2, PR 27D28 and P3619 were efficient in use and responsive to nitrogen application. Besides that, they are recommended for cultivation with low and high technological level.

\section{COMPETING INTERESTS}

Authors have declared that no competing interests exist.

\section{REFERENCES}

1. Neumann $M$, Leão GFM, Coelho MG, Figueira DN, Spada CA, Perussolo LF. Productive, nutritional and bioeconomical aspects of corn hybrids for silage. Arch. Zootec. 2017;253(66):51-58.

2. Kappes C, Arf O, Andrade JAC. Maize grain yield in response to different soil management and nitrogen rates. Rev. Bras. Ciênc. Solo. 2013;37(5):13101321.

Available:https://doi.org/10.1590/S010006832013000500020

3. Taiz L, Zeiger E. Plant physiology. $5^{\text {th }}$ ed. Porto Alegre: Artmed; 2013.

4. Schlichting AF, Silva EMB, Silva MC, Souza WP, Silva TYJA, Farias LN. Efficiency of portable chlorophyll meters in assessing the nutricional status of wheat plants. Rev. Bras. Eng. Agríc. Ambient. 2015;19(12):1148-1151.

Available:https://doi.org/10.1590/18071929/agriambi.v19n12p1148-1151

5. Costa NR, Andreotti M, Gameiro RA, Pariz CM, Buzetti S, Lopes KSM. Nitrogen fertilization in the intercropping of corn with two Brachiaria species in a no-tillage system. Pesq. Agropec. Bras. 2012;47(9): 1038-1047.

Available:https://doi.org/10.1590/S0100204X2012000800003

6. Bender RR, Haegele JW, Ruffo ML, Below FE. Nutrient uptake, partitioning, and remobilization in modern, transgenic insect-protected maize hybrids. Agron. J. 2013;105(1):161-170.

Available:https://doi.org/10.2134/agronj201 2.0352

7. Vieira VC, Martin TN, Menezes LFG, Ortiz $S$, Bertoncelli $\mathrm{P}$, Storck L. Chemical characterization of corn silage. Cienc. Rural. 2013;43(11):1925-1931.

Available:https://doi.org/10.1590/S010384782013001100001

8. Almeida Filho SL, Fonseca DM, Garcia R, Obeid JA, Oliveira JS. Productivity of maize cultivars (Zea mays L.) and quality of components and silage. R. Bras. Zootec. 1999;28(1):7-13.

Available:http://dx.doi.org/10.1590/S151635981999000100002

9. Dubreuil V, Fante KP, Planchon O, Sant'anna Neto JL. Climate change evidence in Brazil from Köppen's climate anual types frequency. Int. J. Climatol. 2018;33:1446-1456.

Available:https://doi.org/10.1002/joc.5893

10. Climatempo. Climatology: Santa Maria das Barreiras - PA.

(Accessed 06 Aug 2020)

Available:https://www.climatempo.com.br/c limatologia/6858/santamariadasbarreiraspa

11. Ribeiro AC, Guimarâes PTG, Alvarez VVH. Recommendations for the use of correctives and fertilizers in Minas Gerais 5th Approximation. Viçosa: Minas Gerais State Soil Fertility Commission; 1999.

12. Pereira Filho IA, Borghi E. Corn seeds: new crop, new cultivars and continues the dominance of transgenics. Sete Lagoas: Embrapa Milho e Sorgo; 2020.

13. Fageria ND, Kluthccouski J. Methodology for evaluation of rice and bean cultivars for adverse soil conditions. Brasília: Embrapa Arroz e Feijão; 1980.

14. Scott A, Knott M. Cluster analysis method for grouping means in analysis of variance. Biometrics. 1974;30:507-512.

15. Ferreira DF. Sisvar: A Guide for its Bootstrap procedures in multiple comparisons. Ciênc. Agrotec. 2014;38(2): 109-112. 
Available:http://doi.org/10.1590/S141370542014000200001

16. Santos WF, Sodré LF, Pelúzio JM, Silva RM, Sales VHG, Melo MP. Effect of low and high nitrogen in corn genotypes cultivated in Tocantins. Revista Cereus. 2019;11(2):12-20.

Available:https://doi.org/10.18605/21757275/cereus.v11n2p12-20

17. Silva ZD, Santos WF, Cerqueira FB, Andrade MR, Dora VC, Fonseca SL, et al. Strategy in the selection of maize genotypes for their efficiency and response to nitrogen. Int. J. Adv. Eng. Res. Sci. 2019;6(11):46-51.

Available:https://doi.org/10.22161/ijaers.61 1.7

18. Pimentel-Gomes F. Experimental Statistics Course. $15^{\text {th }}$ ed. Piracicaba: FEALQ; 2009.

19. Neumann $M$, Horst $E H$, Souza AM, Venancio BJ, Stadler Junior ES, Karpinski RAK. Evaluation of increasing doses of nitrogen in corn cover for silage. Agrarian. 2019;12(44):156-164.

Available:https://doi.org/10.30612/agrarian. v12i44.7195

20. Meira FA, Buzetti S, Andreotti M, Sá ME, Andrade JAC. Sources and times of nitrogen application on irrigated corn crop.
Semina: Ciênc. Agrár. 2009;30(2):275284.

Available:http://dx.doi.org/10.5433/16790359.2009v30n2p275

21. Farinelli R, Lemos LB. Productivity and agronomic efficiency of maize as a function of nitrogen fertilization and soil management. Rev. Bras. Milho Sorgo. 2010;9(2):135-146.

Available:https://doi.org/10.18512/1980-

6477/rbms.v9n2p135-146

22. Cancellier LL, Pinho RGV, Cancellier EL, Pires LPM, Afférri FS, Peluzio JM. Nitrogen use efficiency in forage yield of tropical maize populations. Semina: Ciênc. Agrár. 2014;35(3):1209-1220.

Available:http://dx.doi.org/10.5433/16790359.2014v35n3p1209

23. Fernandes JD, Chaves LHG, Monteiro Filho AF, Vasconcellos A, Silva JRP. Corn growth and yield under the influence of nitrogen split and doses. Espacios. 2017; 38(8):27-42.

24. Rodrigues FJ, Barcarola MA, Adamsb CR, Kleina C, Berwangerc AL. Agronomic efficiency of maize crop under different nitrogen sources in coverage. Uniciências. 2018;22(2):66-70.

Available:http://dx.doi.org/10.17921/14155141.2018v22n2p66-70

(c) 2020 Santos et al.; This is an Open Access article distributed under the terms of the Creative Commons Attribution License (http://creativecommons.org/licenses/by/4.0), which permits unrestricted use, distribution, and reproduction in any medium, provided the original work is properly cited.

Peer-review history:

The peer review history for this paper can be accessed here: http://www.sdiarticle4.com/review-history/60524 